\title{
Supraorbital Notch/Foramen in Sri Lankan Skulls: Morphometry and Surgical Relevance
}

\author{
Escotadura/Foramen Supraorbitario en Cráneos de Sri Lanka: \\ Morfometría y Relevancia Quirúrgica
}

Isurani Ilayperuma*; Ganananda Nanayakkara* \& Nadeeka Palahapitiya*

\begin{abstract}
ILAYPERUMA, I.; NANAYAKKARA, G. \& PALAHAPITIYA, N. Supraorbital notch/foramen in Sri Lankan skulls: morphometry and surgical relevance. Int. J. Morphol., 32(2):435-439, 2014.

SUMMARY: Evidence supports the ethnic and sex variation in the form and position of the supraorbital foramen. Therefore, detailed knowledge of the population specific data on biometric features of the supraorbital foramen will facilitate diagnostic, local anesthetic and surgical manipulations in the maxillo-facial region. The goal of this study was to elucidate the morphological features and precise anatomical position of the supraorbital foramen with reference to surrounding surgically encountered anatomical landmarks in an adult Sri Lankan population. A total of one hundred and eight adult dry skulls of known sex were assessed to determine the number, shape, orientation, vertical and transverse diameters of the supraorbital foramen, transverse distance from the supraorbital foramen to the nasal midline and the zygomatico-maxillary suture and the vertical distance from the supraorbital foramen to the supraorbital rim and infraorbital foramen. The position of the supraorbital foramen was determined in relation to the infraorbital foramen. Data were evaluated between sides and sex. The supraorbital notch $(64.81 \%)$ was found more frequently than the supraorbital foramen (35.19\%). Of the skulls investigated, $55.56 \%$ displayed bilateral supraorbital notches, whereas $20.37 \%$ had bilateral supraorbital foramina and $24.07 \%$ had a notch on one side and a foramen on the contralateral side. The incidence of multiple supraorbital foramina was $6.48 \%$. Sex variations were observed in the relative position of supraorbital notch/foramen from nasal midline (male: $26.12 \pm 3.89$; female: $24.40 \pm 2.76$ ), temporal crest of the frontal bone (male: $32.74 \pm 3.94$; female: $30.87 \pm 4.18$ ) and infraorbital foramen (male: 44.86 \pm 3.35 ; female: 43.26 \pm 3.63 ). The modal position for the infraorbital foramen was lateral to the lateral margin of the supraorbital notch/foramen (68.52\%) and supraorbital and infraorbital foramina were lying in the same sagittal plane only in $24.07 \%$ of the skulls. The results of this study highlight the racial and sex differences and emphasize the need for meticulous preoperative evaluation of the supraorbital foramen to define the optimal locations in patients who are candidates for maxillo-facial surgeries and regional block anesthesia.
\end{abstract}

KEY WORDS: Supraorbital notch/foramen; Position; Sri Lankan.

\section{INTRODUCTION}

The supraorbital margin of the frontal bone is notched or canalized bilaterally near its medial end to form the supraorbital notch/foramen through which the supraorbital nerve and artery exit the skull. The supraorbital nerve is a branch of the first division of the ophthalmic branch of the trigeminal nerve (Sinnathamby, 1999; Williams et al., 2000).

Etiology and pathophysiological mechanisms of various unilateral pain syndromes occurring in the periorbital and frontal region are poorly understood. The peripheral sensory nerves supplying these areas, such as the supraorbital nerve are also considered as putative source of pain. The supraorbital nerve may be affected by swimming goggles or by an anesthetic mask causing neuralgic pain in the forehead (Amsterdam \& Kilgore, 2004).
Regional anesthesia is ideal when the area of interest is innervated by one superficial nerve. The supraorbital nerve supplies sensory innervation to a considerably large area including, the upper eyelid, forehead and scalp as far as the lambdoidal suture, making it a prime candidate for a regional nerve block (Williams et al.; Amsterdam \& Kilgore). Diagnostic and therapeutic supraorbital nerve blocks are used in hemifacial neuralgias and have been systematically performed in various types of headache. Furthermore, supraorbital nerve block is used as an alternative for tissue infiltration in situations such as facial lacerations, forehead and brow lift surgery where tissue distortion would be unacceptable (Amsterdam \& Kilgore; Webster et al., 1986).

The supraorbital notch/foramen is an important 
anatomical landmark to facilitate diagnostic, surgical, local anesthetic and other invasive procedures of the maxillofacial region. Knowledge of the precise location of supraorbital notch/foramen is important in defining the optimal locations for anesthetic nerve blocks, which in turn will invariably reduce the relative risks during clinical procedures (Karakas et al., 2002).

Evidence shows a clear racial variation in the morphometry and relative position of the supraorbital notch/foramen among different populations such as White, Black, Hispanic, Japanese, Thai, Korean and Kenyans (Kimura, 1977; Cutright et al., 2003; Apinhasmit et al., 2006; Aziz et al., 2000; Chung et al., 1995; Agthong et al., 2005; Ongeti et al., 2008). Furthermore, it has been shown that traits such as localization of the facial foramina not only differ between populations of different geographic zones but also within the inhabitants of the same geographic environment (Ari et al., 2005).

Despite its significance little is known concerning the morphological details and the location of the supraorbital notch/foramen in Sri Lankans. Hence, this study was carried out to elucidate the number, shape, dimensions, orientation and position of supraorbital foramen in relation to the surgically encountered anatomical landmarks in an adult Sri Lankan population.

\section{MATERIAL AND METHOD}

A total of one hundred and eight adult dry skulls (70 male and 38 female) collected from the Department of Anatomy, Faculty of Medicine, University of Ruhuna, Sri Lanka, were used for this study. The age group of the cadavers varied between 48-67 years. Both sides of the skulls were assessed and the number, shape, size and orientation supraorbital notch/foramen were recorded by direct visual inspection. The presences of multiple foramina were recorded and the most prominent foramen was considered as the primary structure for characterization. The shape of the supraorbital foramen was described as a notch or a foramen.

The greatest transverse and vertical diameters of the supraorbital notch/foramen were recorded. The transverse straight distance from the center of the supraorbital notch/ foramen to the nasal midline and the temporal crest of the frontal bone and the vertical distance from the supraorbital foramen to the supraorbital rim and infraorbital foramen were measured using a digital sliding caliper (Mitutoyo, Japan) capable of measuring to the nearest $0.01 \mathrm{~mm}$.
The locational relationship of supraorbital notch/ foramen, and infraorbital foramen was classified as follows (Apinhasmit et al.): infraorbital foramen located lateral to the sagittal plane passing through the lateral margin of the supraorbital notch/foramen, between the medial and lateral margins of the supraorbital notch/foramen or medial to the medial margin of the supraorbital notch/foramen.

All the measurements were repeated thrice and the mean was taken for further analysis. Furthermore, the measurements were recorded by the same person to minimize the errors in methodology. Results were expressed as Mean \pm SD and analyzed using the Statistical Package for Social Sciences (SPSS), 15th version. A comparison of the mean values between sides and genders was performed using the ttest. $\mathrm{P}$ value $<0.05$ was considered statistically significant.

\section{RESULTS}

The mean ages of the study subjects (male: $57.5 \pm 12.5$; female 57.0 \pm 10.8 ) were not significantly different between the sexes. All the skulls studied displayed a supraorbital notch/ foramen on both sides. A single supraorbital notch/foramen was present in $93.52 \%$ and multiple foramina were found in $6.48 \%$ of the skulls. Of the skulls that showed multiple foramina, all had double foramina.

The supraorbital notch $(64.81 \%)$ was found more frequently than the supraorbital foramen (35.19\%). Supraorbital notches ranged from mere dents on the superior surface of the orbit to well defined notches. Of the skulls investigated, $55.56 \%$ displayed bilateral supraorbital notches, whereas $20.37 \%$ had bilateral supraorbital foramina and $24.07 \%$ had a notch on one side and a foramen on the contralateral side.

The linear measurements and the anatomical dimensions of the supraorbital notch/foramen with respect to the sides and sexes are summarized in Tables I and II, respectively. These measurements did not vary significantly $(\mathrm{P}>0.05)$ between the sides. Sex variations $(\mathrm{P}<0.05)$ were observed in the relative position of supraorbital notch/foramen from nasal midline, temporal crest of the frontal bone and infraorbital foramen.

The relative position of the infraorbital foramen in relation to the supraorbital notch/foramen was evaluated (Table III). The most common position for the infraorbital foramen was lateral to the lateral margin of the supraorbital notch/foramen $(68.52 \%)$ followed by a position medial to the medial margin of supraorbital notch/foramen (7.41\%). Together, these two positions made an overall prevalence of $75.93 \%$. 
Table I. Morphometric measurements of the SOF between sexes.

\begin{tabular}{lll}
\hline \multirow{2}{*}{ Measurements } & \multicolumn{1}{c}{ Males } & \multicolumn{1}{c}{ Females } \\
\cline { 2 - 3 } & \multicolumn{1}{c}{$($ Mean \pm SD) $\mathbf{m m}$} & \multicolumn{1}{c}{ (Mean \pm SD) mm } \\
\hline Maximum transverse diameter of SON/F & $4.60 \pm 1.67$ & $4.28 \pm 1.06$ \\
Maximum vertical diameter of SON/F & $2.17 \pm 1.10$ & $2.04 \pm 0.97$ \\
Distance from SON/F to NM & $26.12 \pm 3.89$ & $24.40 \pm 2.76^{*}$ \\
Distance from SON/F to TCFB & $31.56 \pm 4.47$ & $29.52 \pm 3.48^{*}$ \\
Distance from SON/F to SOR & $3.46 \pm 1.56$ & $2.98 \pm 1.93$ \\
Distance from SON/F to IOF & $44.86 \pm 3.35$ & $43.26 \pm 3.63^{*}$ \\
\hline
\end{tabular}

$\mathrm{SON} / \mathrm{F}=$ supraorbital notch/foramen; $\mathrm{NM}=$ nasal midline; $\mathrm{TCFB}=$ temporal crest of the frontal bone; $\mathrm{IOF}=$ infraorbital foramen. $*=\mathrm{P}<0.05$.

Table II. Morphometric measurements of the SOF between sides.

\begin{tabular}{lll}
\hline Measurements & \multicolumn{1}{c}{ Right side } & \multicolumn{1}{c}{ Left side } \\
\cline { 2 - 3 } & \multicolumn{1}{c}{ (Mean \pm SD) $\mathbf{~ m m}$} & \multicolumn{1}{c}{ (Mean \pm SD) $\mathbf{~ m m}$} \\
\hline Maximum transverse diameter of SON/F & $4.52 \pm 1.80$ & $4.31 \pm 1.62$ \\
Maximum vertical diameter of SON/F & $2.29 \pm 0.87$ & $2.27 \pm 1.07$ \\
Distance from SON/F to NM & $25.42 \pm 2.49$ & $24.64 \pm 3.16$ \\
Distance from SON/F to TCFB & $32.74 \pm 3.94$ & $30.87 \pm 4.18$ \\
Distance from SON/F to SOR & $3.16 \pm 1.40$ & $3.28 \pm 1.72$ \\
Distance from SON/F to IOF & $45.07 \pm 2.62$ & $44.24 \pm 2.78$ \\
\hline
\end{tabular}

$\mathrm{SON} / \mathrm{F}=$ supraorbital notch/foramen; $\mathrm{NM}=$ nasal midline; $\mathrm{TCFB}=$ temporal crest of the frontal bone; IOF= infraorbital foramen.

Table III. Frequency of the location of IOF in relation to the position of SOF.

\begin{tabular}{lc}
\hline Location of IOF & Percentage \\
\hline Lateral to the lateral margin of SOF & $68.52 \%$ \\
Between the medial \& lateral margins of SOF & $24.07 \%$ \\
Medial to the medial margin of SOF & $7.41 \%$ \\
\hline SOF= supraorbital foramen; IOF= infraorbital foramen
\end{tabular}

\section{DISCUSSION}

The present study provides valuable data on the morphometry and relative location of the supraorbital notch/ foramen in an adult Sri Lankan population, inhabitants of the South Asian country. The precise identification of the supraorbital notch/foramen is important in therapeutic, diagnostic, anesthetic and surgical procedures of the maxillofacial region. Evidence suggests that nerve entrapment mechanisms might play a role in facial neuralgia (Amsterdam $\&$ Kilgore). The passage of the supraorbital nerve through the supraorbital notch and its position adjacent to the frontal bone render it susceptible to injury. Compression of the nerve by scar tissue, intraneural local anesthetics or nerve retraction during surgery may cause supraorbital neuralgia (Amsterdam \& Kilgore).

The observation of the present study that the supraorbital notch/foramen was present in all skulls is consistent with previous studies (Apinhasmit et al.; Chung et $a l$.). The occurrence of supraorbital notch $(64.81 \%)$ was more frequent than foramina $(35.19 \%)$, a result that reinforces the observations of (Apinhasmit et al.; Chung et al.; Ongeti et al.; Gümüsburun et al., 2002; Saylam et al., 2003; TurhanHaktanir et al., 2008). The frequency of the occurrence of supraorbital notch varied (45.9\%-72.9\%) among different populations. Our results pointed to a prevalence of $55.56 \%$ bilateral notching, $20.37 \%$ bilateral foramina and a $24.07 \%$ notch on one side and a contralateral foramen. This was in agreement with the observations of other Asian populations (Webster et al.; Apinhasmit et al.). Furthermore, racial variation in the occurrence of the supraorbital notch is clearly demonstrated by comparative studies between White and Black populations (Cutright et al.; Aziz et al., 2000). Our findings further reinforce the ethnic variation in the occurrence of supraorbital notch/foramen. 
The mean distances from supraorbital notch/foramen to nasal midline, temporal crest of the frontal bone and infraorbital foramen observed in this study were in agreement with those reported in Thais (Apinhasmit et al.) whereas it was different from those of White and Black subjects (Aziz et al.). It is speculated that these differences might be caused by the ethnic factor which confirm the results of previous studies (Kimura, 1977; Cutright et al.; Apinhasmit et al.; Aziz et al.; Agthong et al.; Ongeti et al.). Population specific linear measurements have a clinical implication as it might help precise localization thus avoiding injury to the neurovascular bundle that exit through the supraorbital foramen/notch. Surgically, it may be difficult to accurately locate the nasal midline and in such instances, the distance from temporal crest of the frontal bone is considered to be a better anatomical landmark (Cutright et al.).

The mean distances from supraorbital notch/foramen to the above anatomical landmarks were significantly longer in Sri Lankan males than in females. Our results support sex differences in the position of supraorbital notch/foramen (Kimura; Cutright et al.; Apinhasmit et al.; Agthong et al.; Ongeti et al.). The sex differences in relative position of the supraorbital notch/foramen emphasize the significance of applying the anatomical variation data to an individual subject in a given population (Agthong et al.).

The standard Anatomy texts describe the location of supraorbital and infraorbital foramina on the same sagittal plane (Sinnathamby; Williams et al.). Although this is in accord with some European populations, it ignores a large body of evidence with reference to other populations (Apinhasmit $e t$ al.; Chung et al.; Sicher \& Dubrul, 1991; Mwaniki \& Hassanali, 1992). Such diversity in the location of supraorbital foramen may be attributed to ethnic factors (Cutright et al.; Chung et al.). According to the results of this study, the majority of infraorbital foramina (68.52\%) were located lateral to the supraorbital foramen and only $24.07 \%$ of the study subjects displayed both foramina in the same sagittal plane. Our findings are consistent with the corresponding figures of Thais (Apinhasmit et al.) and Koreans (Chung et al.) highlighting the racial differences in the modal position of the supraorbital foramen in relation to the infraorbital foramina observed among different populations.

The mean transverse and vertical diameters did not vary significantly according to the side or the sex (Ongeti et al.). Information concerning the skull foraminal size and symmetry is increasingly important with the advancement of endoscopic procedures and radiological techniques such as magnetic resonance imaging (MRI) and computed tomography (CT) that makes difficult diagnoses of pathologic conditions of skull foramina possible (Cutright et al.; Berge \& Bergman, 2001).
Incidence of multiple supraorbital foramina among Sri Lankans was found to be $6.48 \%$. The occurrence of multiple supraorbital foramina was shown to be varied widely among different populations (Apinhasmit et al.; Ongeti et al.; Gümüsburun et al.). Multiple facial foramina have been associated with the branching of nerves during development and may explain cases of failure during infiltrative anesthesia for maxillofacial procedures (Martins et al., 2003). Furthermore, the existence of multiple foramina in a minority of patients also has a clinical implication, as injury to any branch of supraorbital nerve that exit through these foramina may result in sensory deficit (Amsterdam \& Kilgore; Aziz et al.).

\section{ACKNOWLEDGEMENTS}

The authors wish to thank Dr. W.A.A. Wijeyasiri, Department of Community Medicine, Faculty of Medicine, University of Ruhuna, Sri Lanka, for advising with the statistical analysis.

\section{ILAYPERUMA， I.; NANAYAKKARA， G. \&} PALAHAPITIYA, N. Escotadura/Foramen supraorbitario en cráneos de Sri Lanka: Morfometría y relevancia quirúrgica. Int. J. Morphol., 32(2):435-439, 2014.

RESUMEN: La evidencia apoya que existe dimorfismo étnico y sexual en la forma y posición del foramen supraorbitario. Por lo tanto, el conocimiento detallado de los datos específicos de una población sobre las características biométricas del foramen supraorbitario facilitará el diagnóstico, anestesia local y procedimientos quirúrgicos en la región maxilofacial. El objetivo fue determinar las características morfológicas y posición anatómica exacta del foramen supraorbitario con referencia a los referencias anatómicas circundantes encontradas quirúrgicamente en una población adulta de Sri Lanka. Ciento ocho cráneos adultos secos de sexo conocido se evaluaron para determinar el número, forma, orientación, diámetros vertical y transversal del foramen supraorbitario, distancia transversal desde el foramen supraorbitario a la línea mediana nasal y sutura cigomático-maxilar y distancia vertical desde el foramen supraorbitario hasta el margen supraorbitario y foramen infraorbitario. La posición del foramen supraorbitario se determinó en relación al foramen infraorbitario. Los datos fueron evaluados según lado y sexo. La escotadura supraorbitaria $(64,81 \%)$ se encontró con mayor frecuencia que el foramen supraorbitario $(35,19 \%)$. El 55,56\% de las escotaduras supraorbitarias y 20,37\% de los forámenes supraorbitarios fueron bilaterales;mientras que el $24,07 \%$ de las escotaduras fueron unilaterales con un foramen en el lado contralateral. La incidencia de los forámenes supraorbitarios múltiples fue del $6,48 \%$. Se observaron variaciones sexuales en la posición relativa de la escotadura/foramen supraorbitario respecto a la línea mediana nasal (hom- 
bres $=26,12 \pm 3,89$; mujeres: $24,40 \pm 2,76$ ), cresta temporal del hueso frontal (hombres $=32,74 \pm 3,94$; mujeres: $30,87 \pm 4,18$ ) y foramen infraorbitario (hombres $=44,86 \pm 3,35$; mujeres $=43,26 \pm 3,63$ ). La posición modal para el foramen infraorbitario fue lateral al margen lateral de la escotadura/foramen supraorbitario (68,52 \%), y los forámenes supraorbitario e infraorbitario se ubicaron en el mismo plano sagital sólo en el 24,07\% de los cráneos. Los resultados muestran las diferencias raciales y sexuales y enfatizan la necesidad de una evaluación preoperatoria minuciosa del foramen supraorbitario para definir su posición en pacientes que son candidatos a cirugías maxilofaciales y bloqueo anestésico regional.

PALABRAS CLAVE: Escotadura/foramen supraorbitario; Posición; Sri Lanka.

\section{REFERENCES}

Agthong, S.; Huanmanop, T. \& Chentanez, V. Anatomical variations of the supraorbital, infraorbital and mental foramina related to gender and side. J. Oral Maxillofac. Surg., 63(6):800-4, 2005.

Amsterdam, J. T. \& Kilgore, K. P. Regional anesthesia of the head and neck. In: Roberts, J. R. (Ed.). Clinical Procedures in Emergency Medicine. $4^{\text {th }}$ ed. Philadelphia, W. B. Saunders, 2004.

Apinhasmit, W.; Chompoopong, S.; Methathrathip, D.; Sansuk, R. \& Phetphunphiphat, W. Supraorbital notch/foramen, infraorbital foramen and mental foramen in Thais: Anthropometric measurements and surgical relevance. J. Med. Assoc. Thai., 89(5):675-81, 2006.

Ari, I.; Kafa, I. M.; Basar, Z. \& Kurt, M. A. The localization and anthropometry of mental foramen on late Byzantine mandibles. Coll. Antropol., 29(1):233-6, 2005.

Aziz, S. R.; Marchena, J. M. \& Puran, A. Anatomic characteristics of the infraorbital foramen: a cadaver study. J. Oral Maxillofac. Surg., 58(9):992-6, 2000.

Berge, J. K. \& Bergman, R. A. Variations in size and symmetry of foramina of the human skull. Clin. Anat., 14(6):406-13, 2001.

Chung, M. S.; Kim, H. J.; Kang, H. S. \& Chung, I. H. Locational relationship of the supraorbital notch or foramen and infraorbital and mental foramina in Koreans. Acta Anat. (Basel), 154(2):162-6, 1995.

Cutright, B.; Quillopa, N. \& Schubert, W. An anthropometric analysis of the key foramina for maxillofacial surgery. J. Oral Maxillofac. Surg., 61(3):354-7, 2003.

Gümüsburun, E.; Katkici, U.; Erdii, H.; Sevim, A. \& Gulec, E. Variations of the supraorbital traits. Morphologie, 86(272):1922, 2002.
Karakas, P.; Bozkir, M. G. \& Oguz, O. Morphometric measurements from different points in the orbit of male Caucasians. Surg. Radiol. Anat., 24(6):358-62, 2002.

Kimura, K. Foramina and notches on the supraorbital margin in some racial groups. Kaibogaku Zasshi, 52(3):203-9, 1977.

Martins, C.; Li, X. \& Rhoton, A. L. Jr. Role of the zygomaticofacial foramen in the orbitozygomatic craniotomy: Anatomic report. Neurosurgery, 53(1):168-73, 2003.

Mwaniki, D. L. \& Hassanali, J. The position of mandibular and mental foramina in Kenyan African mandibles. East Afr. Med. J., 69(4):210-3, 1992.

Ongeti, K.; Hassanali, J. \& Saidi, H. Biometric features of facial foramina in adult Kenyan skulls. Eur. J. Anat., 12(2):89-95, 2008 .

Saylam, C.; Ozer, M. A.; Ozek, C. \& Gurler, T. Anatomical variations of the frontal and supraorbital transcranial passages. J. Craniofac. Surg., 14(1):10-2, 2003.

Sicher, H. \& Dubrul, E. L. Sicher and Dubrul Oral Anatomy. $8^{\text {th }}$ ed. St. Louis, Ishiyaku EuroAmerica Inc., 1991.

Sinnathamby, C. S. Last's Anatomy Regional and Applied. $10^{\text {th }}$ ed. Edinburgh, Churchill Livingstone, 1999.

Turhan-Haktanir, N.; Ayçiçek, A.; Haktanir, A. \& Demir, Y. Variations of supraorbital foramina in living subjects evaluated with multidetector computed tomography. Head Neck, 30(9):1211-5, 2008.

Webster, R. C.; Gaunt, J. M.; Hamdan, U. S.; Fuleihan, N. S.; Giandello, P. R. \& Smith, R. C. Supraorbital and supratrochlear notches and foramina: anatomical variations and surgical relevance. Laryngoscope, 96(3):311-5, 1986.

Williams, P. L.; Bannister, L. H.; Berry, M. M.; Collins, P.; Dyson, M. \& Dussek, J. E. Gray's Anatomy: The Anatomical Masis of Medicine and Surgery. $38^{\text {th }}$ ed. New York, Churchill Livingstone, 2000.

\section{Correspondence to:}

Professor Isurani llayperuma, Ph.D.

Department of Anatomy

Faculty of Medicine, University of Ruhuna

P.O.Box 70, Galle

SRI LANKA

Email: iisurani@yahoo.com

Received: 02-01-2014

Accepted: 21-04-2014 